\title{
ANALYSIS OF THE PROFITABILITY OF MICRO BROILER ENTERPRISES IN CALABAR METROPOLIS, CROSS RIVER STATE.
}

\author{
UKPABUKU, JOSEPH UGAH AND OHEN, SUSANA BEN
}

(Received 14 October 2019; Revision Accepted 7 November 2019)

\begin{abstract}
This study was undertaken to evaluate the profitability micro broiler businesses in Calabar metropolis. The specific objectives of the study were to evaluate the profitability of micro broiler enterprises in Calabar metropolis, analyses selected factors which affects the profitability of micro broiler enterprises and to identify the constraints faced by micro broiler enterprises in Calabar metropolis. It made use of primary data obtained from a random sample of 112 micro broiler operators. The data were analyzed using descriptive statistics, profitability ratios, cost and return analysis and Ordinary Least Square Multiple regression approach. The cost and returns analysis showed that the total variable cost of production per cycle amounted to $\$ 45,931,670.00$ with cost of feed contributing 60.11 percent to the total cost.

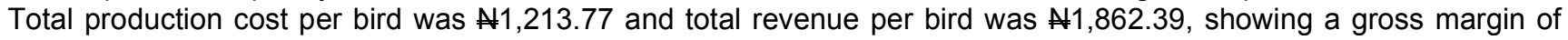
N684.96 and a net income of N648.62 per bird produced. The rate of return on sales (0.35), rate of return on investment $(0.53)$, rate of return on variable cost $(1.55)$ and operating ratio $(0.63)$ all show that micro broiler business in Calabar metropolis was profitable. Output of broiler (flock size) $(p<0.01)$, cost of day old chicks $(p<0.05)$, and transportation fare $(p<0.1)$ were significant to the variation in maximum variable profit. The most dominant constraints identified in the study included; inflationary/recessionary trends, high cost of inputs, poor access to credit, high competition and disease/pest in that order. The study recommended that micro broiler operators should organize themselves into cooperative societies to enable them enjoy the benefits of economies of size and credit facilities from lending agencies. (Word count: 263)
\end{abstract}

KEYWORDS: Profitability, enterprises, micro, broiler, cost and returns

\section{INTRODUCTION}

The need to minimize food scarcity and achieve food security and sufficiency, reduce unemployment and poverty among the populace has been brought to the fore and has received the attention of policy makers and development partners. In line with this, the current administration's agricultural transformation agenda seeks to encourage entrepreneurship in agriculture by addressing challenges of agricultural value chain. Even though Nigeria is blessed with rich human and natural resources and abundant agro allied opportunities, the realization of the full potential of these opportunities has not brought the kind of transformation that is required to take Nigerians out of poverty. Several policy interventions geared toward stimulating the growth and development of entrepreneurship via SME's in agriculture based on technology transfer has failed to yield the desired results. Encouraging broiler businesses has the potential to change the fortunes of this great nation by bringing sustained economic development and growth especially at a time that there is dire need for diversification of the economy.

Broiler enterprise is the rearing of meat-type birds like chickens, turkey, geese, ducks, guinea fowls, quails, etc. with chickens constituting about 86 percent of the total production. According to Food and Agriculture Organization of the United Nations (FAO, 2010), broiler production is an important aspect of poultry business in which the birds are kept for the purpose of providing

Ukpabuku, Joseph Ugah, Department of Agricultural Economics University of Calabar, Cross River State, Nigeria. Ohen, Susana Ben, Department of Agricultural Economics University of Calabar, Cross River State, Nigeria. 
meat for the population. Broiler meat is in very high demand accounting for 36 percent of global meat consumption. The meat is rich in proteins, phosphorus and other minerals as well as B-Complex vitamins. It contains less fat than most cuts of beef and pork, thereby making it a more healthful alternative to red meat.

Effiong and Umoh (2010) observed that the poultry industry as a whole has performed dismally in recent times as a result of inefficiency in resource use. Also the business environment for poultry is volatile and hostile due to a plethora of challenges which includes; high cost of inputs especially feeds, poor management, diseases and pests, lack of adequate extension coverage, problem of marketing, lack of infrastructure, absence of functional regulatory institutions to ensure that farmers conform to laid down standards for product safety and quality and lack of credit facilities. The combined effect of these problems has not only led to low output, but has also militated against capacity building for existing firms as well as making things difficult for new entrants to cope.

\section{Objectives of the study}

The specific objectives of the study includes to;

(i) evaluate the profitability of micro broiler businesses in Calabar metropolis;

(ii) analyses selected factors which affects the profitability of micro broiler businesses in Calabar metropolis;

(iii) identify the constraints faced by micro broiler businesses in Calabar

\section{Analysis of profitability}

Profitability refers to the ability to make profit from an enterprise that is managed by an individual organization or a firm (Ogban, 2015). It shows the technical knowhow of the management by making use of all the resources available to them at the right time to improve on the business. Harward and Upton (1999) define profitability as the ability of a given investment to earn a return from its use. Profitability is an important yardstick for measuring the efficiency of a business and it is expressed in ratio. This group of ratios measures how efficiently a business firm uses its assets and manages its operations. The main concern here being the bottomline net income (Ross, Westerfield \& Jordan, 2008). Apart from efficiency, there exist external and internal factors that affect profitability of a business. The key internal factors being economy of size, farmers age, his/her dedication to the business, efficiency in the use of machinery land productivity and use of managerial technology (Duffy \& Nanhou, 2003). Profitability ratios include;

1. Profit margin $=\frac{\text { Net income }}{\text { Sales }} \times 100$ percent

A high percentage is desirable because it corresponds to low expense ratio relative to sales.

(ii) Return on assets (ROA) = $\frac{\text { Net income }}{\text { Total assets }} \times 100$ percent

It is equivalent to return on investment. It is a measure of profit per naira of assets.

(iii) Return on equity (ROE) = $\frac{\text { Net income }}{\text { Total equity }} \times 100$ percent

Return on equity is a measure of shareholder's funds and as such, it is the true bottom-line performance. Return on equity and return on assets measure performance over a prior period and so they are based on average equity and average assets respectively.

(iv) Gross profit margin $=\frac{\text { Sales-cost of goods sold }}{\text { Sales }}$

$$
=\frac{\text { Gross profit }}{\text { Sales }}
$$

This ratio indicates the average spread between the cost of goods sold and the sales revenue. A high gross profit margin relative to industry average implies that the firm is able to produce at a relatively lower cost. The net profit margin is measured by dividing net profit after tax by sales (Arene, 2002). Gross profit margin is sometimes called gross margin. It highlights the quality of operation performed in a firm and gives the difference between the revenue and total cost. In this study, gross margin is taken as the excess of total revenue over operating cost.

Gross margin $=$ Total revenue $(T R)-$ Total variable cost (TVC).

(v) Return on sales (ROS)

The return on sales (ROS) is a ratio which measures the rate of change in sales over a period of time. Generally, the growth in sales should be considered within the context of the firm's decision and trends of the economies. It is the profit as a percentage of sales and examines the performance in relation to the bottom line (profit or earnings). Higher (ROS) indicates increase in sales made. It enables the farmers to know how much is earned from every sales made. Mathematically, it is expressed as

ROS $=\frac{\mathrm{NI}}{\mathrm{TR}} \times 100$ percent

$\mathrm{NI}=$ Net income, $\mathrm{TR}=$ Total revenue .

(vi) Return on investment (ROI)

Paul, Bendle, Philip and David (2010) define return on investment as the principle of examining basic resource resulting benefit to the investor. A high $\mathrm{ROI}$ signifies that the firm can conveniently cover its cost. As a performance measure, $\mathrm{ROI}$ is used to consider profits in relation to capital and serves as an indicator to compare the investment of different project within a project portfolio.

$\mathrm{ROI}=\frac{\mathrm{NI}}{\mathrm{TC}} \times 100$ percent

$\mathrm{NI}=$ Net income, $\mathrm{TC}=$ Total cost .

\section{METHODOLOGY}

\section{Description of the study area}

The study was carried out in Calabar metropolis covering the two Local Government Areas (Calabar south and Calabar Municipality) in Cross River State, Nigeria. Calabar South has its headquarters at Anantigha and situates on an area of $264 \mathrm{~km}^{2}(102.2$ square miles) and has a population of about 191,630 persons as at 2006 census. Calabar municipality has its headquarters at Marian Road Extension and lies on an area of $142 \mathrm{~km}^{2}$ (55 square miles) and has a population of 179,392 persons as at 2006 census. It is a tourist destination of the State. The combined landmass of the two local government areas lies on latitude $04^{\circ} 34^{\prime} 27^{\prime \prime} \mathrm{N}$ and longitude $6^{\circ} 58^{\prime} 32^{\prime \prime} \mathrm{E}$ and is bounded by Odukpani Local Government Area in the North, Calabar River to the West; the Great Kwa River to the East and the Wetlands of Cross River Estuary to the South. 


\section{Sampling procedure and sample size}

The study population comprised of all micro broiler business owners in Calabar metropolis. A sampling frame for each Local Government Area consisting of a list of practicing broiler business owners were obtained from the Department of Livestock, State Ministry of Agriculture. Broiler businesses in the metropolis were then categorized into micro, small and medium enterprises. All micro enterprises were identified to form the population of the study. The Taro Yamane formula (1960) was applied to each of the list to draw samples. The formula was stated as follows;

$$
\mathrm{n}=\frac{\mathrm{N}}{1+\mathrm{N}(\mathrm{e})^{2}}
$$

Where;

$\begin{array}{lll}\mathrm{n} & = & \text { sample size } \\ \mathrm{N} & = & \text { population size } \\ 1 & = & \text { unity of constant } \\ \mathrm{e} & = & \text { tolerable error }\end{array}$

The samples drawn from each of the Local Government Area (Calabar municipality - 76 and Calabar south - 36) were then merged to obtain a total and final sample size of 112 micro broiler business owners. Simple random technique was then used to select firm owners

\section{Method of data collection}

Data were generated from primary sources. Primary data were collected through field survey from operators of broiler businesses in the study area using questionnaire, interviews and observations. Information were also collected from records of broiler operators such as invoices and sales day books.

\section{Research instruments}

Since the study involved a survey design, the main instruments used in gathering data were structured questionnaire and interviews. The questionnaire was developed to adopt the closed-ended/structured statements. The questionnaire was self-administered and retrieved. Oral interviews were conducted to enable the researcher obtain some clarity on certain issues that questionnaire could not adequately address. The interviews were self-administered.

\section{Data analysis technique}

The questionnaire were checked for completion and then coded. Qualitative analysis consisted of examining, categorizing, tabulating and recombining evidences to address research questions. The data were grouped into meaningful patterns and themes according to observations to help in summarizing and organization of data. Descriptive statistical techniques such as frequency counts, percentages, arithmetic mean were used for analysis. Inferential statistics used was multiple regression analysis and profit function.

1. Objective I was analyzed using gross margin and profitability analysis.

2. Objective II was analyzed using profit function to determine the effect of selected factors on the profitability of micro broilers businesses in Calabar metropolis.

3. Objective III was analyzed using descriptive statistics (frequency count and means) to outline the constraints faced by micro broiler business owners in Calabar metropolis.

\section{Model specification}

The cost and return analysis

Cost and return analysis was used to determine the cost and revenue structure of broiler businesses

TC $=$ TFC + TVC

Where;

$$
\begin{array}{lll}
\mathrm{TC} & = & \text { Total cost } \\
\mathrm{TFC} & = & \text { Total fixed cost }
\end{array}
$$

TVC $=$ Total variable cost

Total variable cost (TVC) consisted of all the operating cost incurred by the firm, from stocking to point of sale (market size) times the number of production cycles in a year.

Total revenue (TR) consist of receipts from total sales (Gross revenue $=$ Quantity produced $\mathrm{x}$ price per bird $\mathrm{N}$ )

Fixed costs: Are cost which do not vary with output. Fixed cost in this study includes rent on land, cost of housing, drinkers, feeders, lantern, stoves, generators and shovel/spades. The values of the fixed cost items were subjected to depreciation except rent on buildings. Depreciation is the allowance in monetary terms for the value of fixed cost being used up in production activities. The straight line depreciation was used because the method is best suited for assets with short and predictable useful life (Certified Practicing Accountant of Australia, 2012).

Depreciation $=\frac{\text { Cost-Salvage value }}{\text { Useful life }}$

Depreciation is the annual depreciation. Cost is the purchase cost of the item. Salvage value is the value of items after their useful life. In this study, since the fixed cost items are not resold after use, their salvage values are assumed to be zero. Useful life refers to the length of time that a fixed cost item is used until it is no longer useful for its purposes.

Variable cost (VC) refers to cost that varies according to output level. They are directly proportional to output volume and increases as output increases and decreases as output decreases. In this study, variable cost includes; cost of day old chicks, feeds, medication/vaccines, labour, transportation, energy, water, sawdust/wood shaving, etc. Revenue in this study refers to all cash receipts from the sale of broilers and litter.

Gross margin

$$
\begin{gathered}
\text { Gross profit margin }=\frac{\text { Sales }- \text { Cost of goods sold }}{\text { Sales }} \\
=\frac{\text { Gross profit }}{\text { Sales }}
\end{gathered}
$$

The gross profit margin reflects the efficiency with which management produces each unit of broiler bird. A high gross profit margin will be a sign of good management. A low ratio will reflect high cost of goods sold due to firm's inability to purchase inputs at favoruable terms, inefficient use of fixed and variable resources.

Gross margin is obtained by subtracting the total variable cost from the total revenue. Olukosi and Erhabor (1989) gave the expression for gross margin as

Where;

$$
\mathrm{GM}=\mathrm{TR}-\mathrm{TVC}
$$

$\mathrm{GM}=$ Gross margin $(\mathrm{N})$

$\mathrm{TR}=$ Total revenue (A)

TVC $=$ Total variable cost $(\mathbb{A})$

Profitability ratios

Rate of return on investment (ROI)

The rate of return on investment (ROI) was used to evaluate the improvements made by the various firms. It 
was obtained by dividing the firms net income by its total cost and is calculated as;

Where;

$$
\mathrm{ROI}=\frac{\mathrm{NI}}{\mathrm{TC}} \times 100 \text { percent }
$$

$\mathrm{NI}=$ Net income

$\mathrm{TC}=$ Total cost

Return on sales (ROS)

This is the profit or earnings as a percentage of sales and it was used to examine the performance of the business in relation to the profit earned. Higher ROS indicates increase in sales. It is calculated thus: ROS = $\frac{\mathrm{NI}}{\mathrm{TR}} \times 100$ percent

Where;

$\mathrm{NI}=$ Net income

$\mathrm{TR}=$ Total revenue

Rate of return on variable cost $=\frac{\mathrm{TR}-\mathrm{TFC}}{\mathrm{TVC}}$

Operating ratio $=\frac{\mathrm{TVC}}{\mathrm{TR}}$

Net income (NI)

The net income was employed to estimate the profitability of micro broiler business.

$\mathrm{NI}=\mathrm{GI}-\mathrm{TVC}$

Where;

$$
\begin{array}{lll}
\mathrm{NI} & = & \text { Net income }(\mathrm{N}) \\
\mathrm{GI} & = & \text { Gross income }(\mathrm{N}) \\
\mathrm{TVC} & = & \text { Total variable cost }(\mathrm{N})
\end{array}
$$

Measurement of performance

Objective (iv): In this study, profitability was used as a measure of performance. The generalized profit function adopted from Arene (2002) was used to analyze the effect of selected factors on profitability.

$\Pi *=\pi *\left(\mathrm{p}_{\mathrm{y}}, \mathrm{p}_{1}, \mathrm{p}_{2}, \mathrm{p}_{3}, \mathrm{p}_{4}, \mathrm{p}_{5}, \mathrm{p}_{6}, \mathrm{p}_{7}, \mathrm{p}_{8}\right)$

Where;

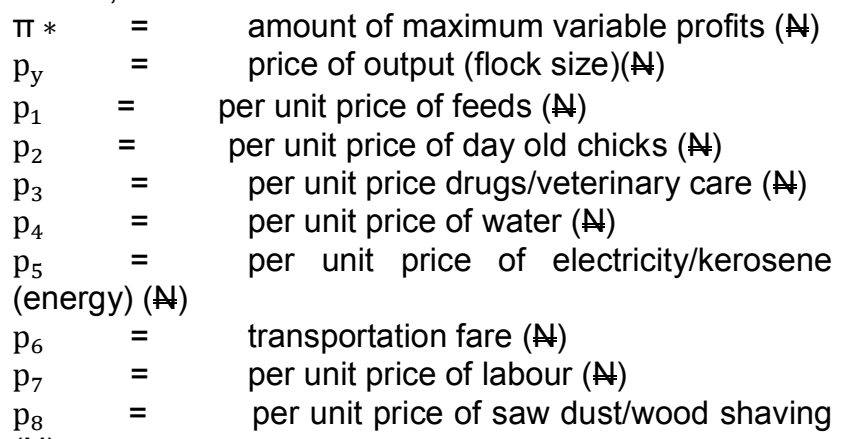


ANALYSIS OF THE PROFITABILITY OF MICRO BROILER ENTERPRISES IN CALABAR METROPOLIS,

Findings

Profitability analysis of micro broiler businesses

Table 1

One cycle cost/returns and profitability analysis of poultry enterprises

\begin{tabular}{|c|c|c|c|c|}
\hline Item & $\begin{array}{l}\text { Total costs/returns } \\
\text { (112 farmers) }\end{array}$ & Mean costs/returns & Cost/returns $p$ & er bird \\
\hline Costs and returns & & & & \\
\hline Total revenue from (TR) & $72,651,750$ & 648,676 & 1862.39 & \\
\hline Total variable cost (TVC) & $45,931,670$ & 410,104 & $1,177.43$ & \\
\hline Total fixed costs (TFC) & $1,417,340$ & 12,655 & 36.33 & \\
\hline Total cost (TC) & $47,349,010$ & 422,759 & $1,213.77$ & \\
\hline Gross margin (GM) & $26,720,080$ & 238,572 & 684.96 & \\
\hline Net income $(\mathrm{NI})$ & $25,302,740$ & 225,917 & 648.62 & \\
\hline Profitability analysis & & & & \\
\hline Return on sales & 0.35 & 0.35 & & \\
\hline Rate of return on investment & 0.53 & 0.53 & & \\
\hline Rate of return on variable cost & 1.55 & 1.55 & & \\
\hline Operating ratio & 0.63 & 0.63 & & \\
\hline Summary of variable cost & $\begin{array}{l}\text { Total costs }(1 \\
\text { farmers) }\end{array}$ & $12 \begin{array}{l}\text { Mean costs } \\
\text { (Naira) }\end{array}$ & $\begin{array}{l}\text { Percentage of } \\
\text { variable cost }\end{array}$ & \\
\hline Day old chicks & $10,773,00.00$ & $96,187.50$ & 23.45 & 276.16 \\
\hline Feeds & $27,611,000.00$ & $246,526.79$ & 60.11 & 707.79 \\
\hline Medication/vaccines & $2,570,290.00$ & $22,949.02$ & 5.60 & 65.89 \\
\hline Water & $461,700.00$ & $4,122.32$ & 1.01 & 11.84 \\
\hline Electricity/kerosene (energy) & $840,880.00$ & $7,507.86$ & 1.83 & 21.56 \\
\hline Transportation & $1,054,900.00$ & $9,418,75$ & 2.30 & 27.04 \\
\hline Labour & $2,358,000.00$ & $21,053.57$ & 5.13 & 60.45 \\
\hline Saw dust & $237,900.00$ & $2,124.11$ & 0.52 & 6.10 \\
\hline Other cost & $24,000.00$ & 214.29 & 0.05 & 0.62 \\
\hline Total variable costs & $45,931,670.00$ & $410,104.20$ & 160.00 & $1,177.43$ \\
\hline Summary of fixed cost items & $\begin{array}{l}\text { Total costs for a cyc } \\
\text { (112 farmers) }\end{array}$ & $\begin{array}{l}\text { Mean costs for } \\
\text { a cycle (Naira) }\end{array}$ & $\begin{array}{l}\text { Percentage to } \\
\text { fixed cost }\end{array}$ & \\
\hline Housing & $1,113,251.56$ & $9,939.75$ & 78.55 & 28.54 \\
\hline Drinkers & $86,536.09$ & 772.64 & 6.11 & 2.21 \\
\hline Feeders & $75,824.84$ & 677.01 & 5.35 & 1.94 \\
\hline Stove & $62,430.83$ & 557.42 & 4.40 & 1.60 \\
\hline Lantern & $35,461.13$ & 316.62 & 2.50 & 0.91 \\
\hline Wheel barrow & $31,977.00$ & 285.51 & 2.26 & 0.82 \\
\hline Shovel & $11,858.38$ & 105.88 & 0.84 & 0.30 \\
\hline Total fixed costs & $1,417,339.83$ & $12,654.82$ & 100.00 & 36.33 \\
\hline
\end{tabular}

Source: Field survey, 2017. 
The performance of the firms was evaluated using cost and returns analysis and profitability ratios. Table 1 shows that cost of feeds accounted for 60.11 percent of the total variable cost (TVC) of production. Most micro broiler operators keep birds beyond the standard 8 weeks thereby incurring more cost. This is followed by cost of day old chicks 23.45 percent. Obviously, feeds constitute the biggest subhead for cost coupled with the prevailing high cost of inputs. Medication, labour, transportation, electricity/kerosene (energy), water, sawdust/wood shaving accounted for 5.60, 5.13, 2.30, 1.83, 1.01 and 0.52 percent respectively in that order. Other cost (miscellaneous and contingent expenses) accounted for 0.05 percent of total variable cost. Also, the table shows that, depreciation on housing took more than half of the TFC accounting for 78.55 percent. Depreciation on other equipment accounted for 6.11 , $5.35,4.40,2.50,2.26$ and 0.84 percent for drinkers, feeders, stove, lantern, wheelbarrow and shovel respectively. Table 9 also shows the cost benefit analysis of micro broiler businesses in the study area. The analysis shows a total production cost per birds in the study area to be $A 1,213.77$ and total revenue per bird to be $\$ 1,862.39$. This shows that micro broiler operators in the study area earned a gross margin of \$684.96 and a net income of $\$ 648.62$ per bird produced. It can be inferred that there is ample potential for profitable micro broiler business in the study area since broiler production is a short gestation enterprise that last for about two months for a production cycle, implying that repeating the production cycle many times in a year depending on the market situation will be good for business. This result is in line with Emaikwu et al. (2011) which state that repeating the production cycle three to four times in a year depending on the level of demand will sustain the broiler producers economically and dietarily in the study area.
On the average, a micro broiler operator earn a gross

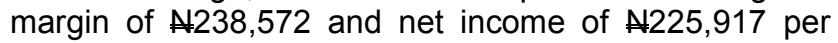
cycle of operation involving a mean flock size of 348 birds. This means that the micro broiler businesses earn good returns in the study area. Return on sales gave a profitability index of 0.35 which implies that micro broiler businesses earn 35 kobo as net income from every $\mathrm{N} 1$ (naira) of sales. With low profitability index of less than 1, micro broiler operators need to adopt better management practices to be able to generate more profit. The rate of return on investment of 0.53 shows that micro broiler business operators in the study area

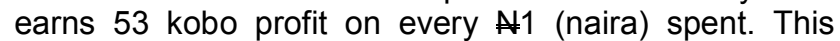
shows that, though the cost of running a micro broiler business in the study area is high, a relatively high profit could still be achieved. The rate of return on variable cost is estimated to be 1.55 which imply that every $\mathrm{N} 1$ (naira) cost incurred on variable inputs generates about $\$ 1.55 \mathrm{~K}$. This will require improvement in the efficiency of use of variable inputs in order to increase the profitability. The operating ratio of 0.63 indicates that the total variable cost is about 63 percent of the total revenue which is high and not good for business. Generally, profitability indicators show that micro broiler business is profitable in the study area. But in order to raise the profitability index to 1 and reduce the operating ratio, management issues needs to be addressed.

\footnotetext{
Factors affecting performance of micro broiler businesses

Profitability is used as a measure of performance. Four functional forms with the generalized profit function were specified to analyze factors that affect profitability. Profitability of the firms was assessed using amount of maximum variable profit. The exponential model gave the best fit with an $\mathrm{R}^{2}$ of 97 percent and three significant variables.
} 
Table 2

Factors affecting the profitability of micro broiler businesses in Calabar metropolis

\begin{tabular}{|c|c|c|c|c|c|}
\hline & Linear & Exponential $(+)$ & & Semi-log & Double Log \\
\hline Constant & $\begin{array}{l}-388990 \\
(244234)\end{array}$ & $\begin{array}{l}6.65036^{* * *} \\
(0.0384)\end{array}$ & & $\begin{array}{l}12.5967^{* * *} \\
(3.280)\end{array}$ & $\begin{array}{l}15.1440 \\
(20.345)\end{array}$ \\
\hline Py & $\begin{array}{l}82.964^{*} \\
(46.84)\end{array}$ & $\begin{array}{l}0.000429440 \\
(7.37 e-06)\end{array}$ & *** & $\begin{array}{l}-0.00227366^{\star * *} \\
(0.0006291)\end{array}$ & $\begin{array}{l}-4.37240^{* * *} \\
(1.462)\end{array}$ \\
\hline P1 & $\begin{array}{l}-14.8684 \\
(46.36)\end{array}$ & $\begin{array}{l}9.53349 \mathrm{e}-06 \\
(7.291 \mathrm{e}-06)\end{array}$ & & $\begin{array}{l}-0.000684658 \\
(0.000622)\end{array}$ & $\begin{array}{l}-1.33440 \\
(2.023)\end{array}$ \\
\hline P2 & $\begin{array}{l}696.471 \\
(552.53)\end{array}$ & $\begin{array}{l}0.000179219^{\star *} \\
(8.689 \mathrm{e}-05)\end{array}$ & & $\begin{array}{l}0.0153576 \text { ** } \\
(0.00742)\end{array}$ & $\begin{array}{l}3.59720^{* *} \\
(1.614)\end{array}$ \\
\hline P3 & $\begin{array}{l}7.17599^{* * *} \\
(1.25)\end{array}$ & $\begin{array}{l}2.06346 \mathrm{e}-07 \\
(1.963 \mathrm{e}-07)\end{array}$ & & $\begin{array}{l}1.55048 \mathrm{e}-05 \\
(1.677 \mathrm{e}-05)\end{array}$ & $\begin{array}{l}-0.0548031 \\
(0.1157)\end{array}$ \\
\hline P4 & $\begin{array}{l}-1.01290 \\
(2.159)\end{array}$ & $\begin{array}{l}-4.88839 e-07 \\
(3.396 e-07)\end{array}$ & & $\begin{array}{l}-1.80420 e-05 \\
(2.90 e-05)\end{array}$ & $\begin{array}{l}-0.0354055 \\
(0.0402)\end{array}$ \\
\hline P5 & $\begin{array}{l}-0.484020 \\
(4.367)\end{array}$ & $\begin{array}{l}-8.25992 \mathrm{e}-07 \\
(6.868 \mathrm{e}-07)\end{array}$ & & $\begin{array}{l}8.60365 \mathrm{e}-05 \\
(5.866 \mathrm{e}-05)\end{array}$ & $\begin{array}{l}1.22505^{* * *} \\
(0.446)\end{array}$ \\
\hline P6 & $\begin{array}{l}0.458976 \\
(0.9223)\end{array}$ & $\begin{array}{l}2.42067 \mathrm{e}-07^{*} \\
(1.450 \mathrm{e}-07)\end{array}$ & & $\begin{array}{l}1.50888 \mathrm{e}-05 \\
(1.24 \mathrm{e}-05)\end{array}$ & $\begin{array}{l}0.293905 \\
(0.199)\end{array}$ \\
\hline P7 & $\begin{array}{l}-1.26954 \\
(1.564)\end{array}$ & $\begin{array}{l}-7.11156 \mathrm{e}-08 \\
(2.459 \mathrm{e}-07)\end{array}$ & & $\begin{array}{l}1.94202 \mathrm{e}-05 \\
(2.10 \mathrm{e}-05)\end{array}$ & $\begin{array}{l}0.251423 \\
(0.378)\end{array}$ \\
\hline P8 & $\begin{array}{l}81.7054^{* * *} \\
(20.452)\end{array}$ & $\begin{array}{l}-1.65624 \mathrm{e}-07 \\
(3.217 \mathrm{e}-06)\end{array}$ & & $\begin{array}{l}0.000347307 \\
(0.00027)\end{array}$ & $\begin{array}{l}0.737715 \\
(0.553)\end{array}$ \\
\hline Diagnostic & & & & & \\
\hline $\mathrm{R}^{2}$ & 0.624 & 0.975 & & 0.261 & 0.244 \\
\hline Adj $R^{2}$ & 0.59 & 0.972 & & 0.195 & 0.177 \\
\hline F-stat & $18.429^{* \star *}$ & $434.21^{* * *}$ & & $3.93^{* * *}$ & $3.65^{\star \star *}$ \\
\hline SE & 120290.1 & 0.0189 & & 1.6156 & 1.619 \\
\hline
\end{tabular}

Source: Field survey data, 2018

Figures in parentheses are standard error; *, **, *** means significant at 10,5 and 1 percent ; Py $=$ Price of output; P1 = per unit price of feeds (\#); P2=per unit price of day old chicks (\#) ; P3 =per unit price of drugs/veterinary care (\#), P4 =per unit price of water (\#) ; P5 =per unit price of electricity/kerosene (\#); P6 $=$ transportation fare (\#), P7=per unit price of labour ;P8 =per unit price of saw dust/wood shaving(\#).

Table 2 shows that nine explanatory variables accounted for 97 percent of the variability in the amount of maximum variable profit of micro broiler businesses in
Calabar metropolis. Out of nine explanatory variables analyzed; three were significant to the variation in amount of maximum variable profit. They include output of broiler (flock size) $(P<0.01)$, cost of day old chicks $(P<0.05$ and transportation fare $(P<0.1)$. F-value of 434.21 was significant at 1 percent, indicating an overall good fit of the model. The result shows that most of the farmers were making profit within the rational area of the profit function using all the variable cost items. Fixed costs were not analyzed since the analysis was based on the short-run effect of input cost. This is in consonant with

Arene

(2002). 
Table 3

Constraints faced by micro broiler businesses in Calabar metropolis

\begin{tabular}{|c|c|c|c|c|c|c|c|c|c|}
\hline $\mathrm{S} / \mathrm{N}$ & Constraints & $\mathrm{SA}(5)$ & $A(4)$ & $\mathrm{DK}(3)$ & $\mathrm{D}(2)$ & $\mathrm{SD}(1)$ & Sum & Mean & $\begin{array}{l}\text { Ran } \\
\text { k }\end{array}$ \\
\hline 1. & Government policies(Taxes, lending rates) & $5(25)$ & $64(256)$ & $20(60)$ & $23(46)$ & - & 387 & 3.46 & $12^{\text {th }}$ \\
\hline 2. & High cost of input( feeds, day-old chicks, drugs) & $73(3650$ & $38(152)$ & - & $1(2)$ & - & 519 & 4.63 & $2^{\text {nd }}$ \\
\hline 3. & $\begin{array}{l}\text { Non-availability of inputs(feeds, day-old chicks, } \\
\text { drugs) }\end{array}$ & $32(160)$ & $64(256)$ & - & $15(30)$ & $1(1)$ & 447 & 3.99 & $8^{\text {th }}$ \\
\hline 4. & $\begin{array}{l}\text { Absence of infrastructural facilities(incubation } \\
\text { centres) }\end{array}$ & 13(65) & $83(332)$ & $6(18)$ & $10(20)$ & - & 435 & 3.88 & $10^{\text {th }}$ \\
\hline 5. & High competition & $71(355)$ & $36(144)$ & $2(6)$ & $3(6)$ & - & 511 & 4.56 & $4^{\text {th }}$ \\
\hline 6. & $\begin{array}{l}\text { Changing consumer behavior and income causing } \\
\text { low product }\end{array}$ & $15(75)$ & $90(360)$ & 2(6) & $5(10)$ & - & 451 & 4.03 & $7^{\text {th }}$ \\
\hline 7. & Inflationary/recessionary trends & $95(475)$ & $16(64)$ & - & $1(2)$ & - & 541 & 4.83 & $1^{\text {st }}$ \\
\hline 8. & Poor access to credit & $80(400)$ & 24(96) & $7(21)$ & 1(2) & - & 519 & 4.63 & $2^{\text {nd }}$ \\
\hline 9. & Poor extension services & $9(45)$ & $76(304)$ & $13(39)$ & $14(28)$ & - & 416 & 3.71 & $11^{\text {th }}$ \\
\hline 10. & Low product market price & 13(65) & $91(364)$ & $2(6)$ & $6(12)$ & - & 447 & 3.99 & $8^{\text {th }}$ \\
\hline 11. & Poor management practices & $1(5)$ & $58(232)$ & $10(30)$ & $41(82)$ & $2(2)$ & 351 & 3.13 & $14^{\text {th }}$ \\
\hline 12. & Multiple taxation & $4(20)$ & $53(212)$ & $25(75)$ & $30(60)$ & - & 367 & 3.28 & $13^{\text {th }}$ \\
\hline 13. & Disease and pest & $51(255)$ & $58(232)$ & $1(3)$ & $1(2)$ & 1(1) & 493 & 4.40 & $5^{\text {th }}$ \\
\hline 14. & High transportation cost & $12(60)$ & $97(388)$ & - & $2(4)$ & 1(1) & 453 & 4.05 & $6^{\text {th }}$ \\
\hline
\end{tabular}

Note: Weighted mean $=3.00, S A=$ Stronglyagree, $A=$ Agree,$D K=$ Don't know,$D=$ Disagree, $S D=$ Strongly disagree .

Source: Field survey, 2017. 
CONSTRAINTS FACED BY MICRO BROILER BUSINESSES

Table 3 shows constraints faced by micro broiler operators in the study area. Constraints are ranked according to how severe they affected broiler production. Inflationary/recessionary trends are ranked first 4.83 followed by high cost of inputs and poor access to credit 4.63. This is in line with Emaikwu et al. (2011), Agbato (1997) and Akeeb (1997) which revealed that, credit facilities and loans from financial institutions are not accessible to the poultry farmers, couple with high feed cost, inadequate capital. Other constraints included high competition (4.56) and disease and pest (4.40). The result also conforms to Kehinde et al. (2016) and Folorunso et al. (2016) which stated that poor pricing, marketing, disease outbreak, inadequate capital and credit facilities were major constraints faced by poultry producers.

\section{CONCLUSION}

From the analysis thus far, the study concluded that though the cost of operating micro broiler business in Calabar metropolis was very high, the entrepreneurs still earned relatively high profit and returns from their entrepreneurial activities. On the average, a micro broiler operator makes a gross margin of N238,572 and net income of N225,917 per cycle of operation for mean flock size of 348 birds. Furthermore, the cost per bird, total revenue per bird, gross margin per bird and net income per bird was $\$ 1,213.77$, $\$ 1,862.39, \$ 684.95$ and $\$ 648.62$, respectively. The rate of return on sales, rate of return on investment, rate of return on variable cost and operating ratio were estimated to be 0.35 , $0.53,1.55$ and 0.63 respectively, which combined to suggest that micro broiler business is profitable in Calabar metropolis. The analysis also emphasized that the ability of the entrepreneur to control production cost is key to the success of the micro broiler business. For the entrepreneur to stay afloat in business, he must possess the necessary skills and experience to be able to maintain a lower cost structure through good and efficient management practices. The entrepreneur with these qualities is able to achieve significant reduction in the per unit variable cost of broiler, hence boosting his competitive advantage and increasing the net income of the business, which ensures the survival of the business, in the long run. The study recommended that broiler operators should organize themselves into cooperative associations to put them in good stead to be able to access the much needed capital from funding agencies. This will enable them to be able to pay for some of the innovative technologies and inputs that are required in modern day broiler operations. There should be deliberate and conscious efforts to subsidize the cost of feeds and day old chicks as a policy action as well as instituting a flexible credit policy for broiler operators in the area to reduce cost and increase profits made by broiler operators.

\section{REFERENCES}

Agbato, O. A., 1997. Effective strategies for egg marketing in Nigeria. Paper presented at a workshop organized by Nigeria Society for Animal Production (NSAP), Ogun State.

Akeeb, S., 1997. Problems of poultry production in Nigeria. Paper Presented at a Workshop Organized by Nigeria Society for Animal Production (NSAP), Ogun State.

Arene, C. J., 2002. Economic analysis of agricultural and rural development projects. Nsukka: Fulladu Publishing Company.
Arene, C. J., 2002. Profit function analysis of small ruminant enterprises in Nsukka Local Government Area of Enugu State, Nigeria. Quarterly Journal of Economics, 47(4), 209-214.

Certified Practicing Accountant, Australia CPA Australia, 2012. Guide to valuation and depreciation under the international accounting standards for the public sector. Australia: CPA Australia Ltd, Southbank VIC 3006, 70-71.

Duffy, M. and Nanhou, V., 2003. Factor in the success of farms and the relationship between financial success and perceived success. Ames: Yowa State University, Staff General Research Paper.

Effiong, E. O. and Umoh, G. S., 2010. Cobb Douglas production function with composite error term in egg laying enterprises in Akwa Ibom State, Nigeria. Journal of Tropical Agriculture, Food, Environment and Extension, 9(1), 1-7.

Emaikwu, K. K., Chikwendu, D. O. and Sani, A. A., 2011. Determinants of flock size in broiler production in Kaduna State of Nigeria. Journal of Agricultural Extension and Rural Development, 3(11), 202-211.

Folorunso, S. T., Abia, E., Okoroji, E. O., Dawang, N. C. and Binuyo, G., 2016. Profitability analysis of layer poultry production in Jos metropolis, Plateau State, Nigeria. National Annual Production Research Institute, Zaria. Journal of Animal Production Research, 28(1), 169-178.

FAO (2010). Poultry meat and eggs: Agribusiness handbook. www.fao.org.

Harward and Upton 1999. Introduction to business finance. New York: McGraw Hill.

Kehinde, E. A., Nduka, M. C., Uchendu, C. U. and Kehinde, W. H. 2-16. Analysis of socio-economic and institutional factors influencing poultry farmers' production in Sabon-Gari Local Government Area, Kaduna State. Journal of Animal Production Resources, 28(2), 279-286.

Ogban, G. O., 2015. Comparative Economic Analysis of Fish Farming Production Systems in the Southern Agricultural Zone of Cross River State, Nigeria. M.Sc. Thesis submitted to Department of Agricultural Economics, University of Calabar.

Olukosi, J. O. and Erhabor, P. O., 1989. Introduction to agricultural production economics. Zaria: Agitab Publishers.

Paul, W. F., Bendle, N. T., Philip, E. P. and David, J. R., 2010. Marketing metrics: The definitive guide to measuring marketing performance. Pearson (eds) London.

Ross, S. A., Westerfield, R. W. and Jordan, B. D., 2008. Fundamentals of corporate finance. (8th ed.). New York: Mc-Graw-Hill Irwin. 
